\title{
INTERPERSONAL COMMUNICATION SKILLS OF DYSLEXIC CHILDREN AND IMPLICATIONS FOR GUIDANCE AND COUNSELING SERVICES
}

\section{Dody Hartanto, Muya Barida*, Arbin Janu Setyowati, Fitri Saraswati *Correspondent Author}

Dody Hartanto

Universitas Ahmad Dahlan

Jalan Ring Road Selatan Yogyakarta, Indonesia

Email: dody.hartanto@bk.uad.ac.id

Muya Barida

Universitas Ahmad Dahlan

Jalan Ring Road Selatan Yogyakarta,

Indonesia

Email: muya.barida@bk.uad.ac.id

Arbin Janu Setyowati

Universitas Negeri Malang

Jalan Semarang Nomor 5 Sumbersari,

Lowokwaru, Kota Malang

Indonesia

Email: arbinjs_rk@ymail.com

Fitri Saraswati

Universitas Ahmad Dahlan

Jalan Ring Road Selatan Yogyakarta, Indonesia

Email:

fitri1500001182@webmail.uad.ac.id

Page

$1-9$

\begin{abstract}
Interpersonal communication skills are very important possessed by every individual. This study aims to examine how communication skills possessed by dyslexic children, given that dyslexic children experience language barriers. The study was conducted using a qualitative approach through the case study method of three students at Griya Baca Pelangi who had been diagnosed with dyslexia. Data was collected through observation, interview, and documentation techniques. Next, the data were analyzed with the concept of Miles and Huberman. The results were obtained that the dyspersic communication skills of dyslexic children differ. In guidance and counseling services, communication skills of dyslexic children can be improved through group guidance services and can also be combined with responsive services in the form of individual counseling or group counseling

Keywords: dyslexia, communication barriers, children with special needs, interpersonal communication
\end{abstract}

\section{INTRODUCTION}

Dyslexic children are often assumed as children who have learning delay by the people, it because of dyslexic children have difficulties differentiating the letter. This matter is supported by ljeoma (2018), who stated that dyslexia is a neurologist condition that influences a student's ability to follow the principle of the alphabet from the phoneme correspondences to grapheme, so dyslexia will has difficulties in mastering reading and spelling. Therefore, this condition causes the dyslexic children to experience an academic failure.

The language development of dyslexic children often has a problem. However, dyslexic children have an excess that the normal children in their age cannot afford, such as the ability to describe a picture. For example, if dyslexic children given a picture of 


\section{2। PSIKOPEDAGOGIA}

a person riding a tractor and coconut tree places in front of him; the background of the picture is the high seas, they will describe the picture has a wide and clear sea. However, compared with the normal children, they will see a person riding a tractor and a coconut tree in front of him. Additionally, Bilgehan (2017); Flaugnacco et al. (2015); BishopLiebler et al. (2014) stated that dyslexic children have some characteristics; they have different difficulties. That characteristic is being the strength for dyslexic children. However, it will not be easy to develop if the parents and the teacher do not know it.

The lack of teacher and parents' knowledge will be the obstacle for dyslexia. The teacher should give a teaching that is easy to understand by all dyslexic children. The teaching process also should use a different method than the method used to teach normal children. Dyslexic children need a learning place that understands what they are going through. The education and the teacher's willingness to accept the lack and the excess become the sense of pride for a dyslexic child. The support from the parents and the teacher are really important for their growth in academic cases or non-academic cases. Dyslexic children struggle by having many talents and excess because they should learn how to control their creativity and imagination when they are in school (Amin, 2018; Devina \& Penny: 2016).

Communication becomes a discussion that seems trivial, but everything starts from communication. Therefore, communication is one matter that the individual should develop. This case is also strengthened by Ningsih, Legowo, \& Hidayat (2017), who stated that students need to have communication skills for expressing their thought and idea to their friend or their teacher in the learning process.

Many schools have less attention on the communication for the children with special needs, so if that matter is ignored, it will be an obstacle for dyslexic children and the teacher or the parents in the matters of dyslexic children's future life, although the fact that dyslexic children have superior intelligence. If the teacher can facilitate the dyslexic child's difficulties, it will be possible that the child with special needs (dyslexia) can be equal and comparable with the normal children who have the same ability.

The understanding about communication of dyslexic child needs to be dug up and developed; it is for giving the information about how important the communication skill that dyslexic children should master. Communication skill is very helpful for their interaction in the social environment. Communication does not only help dyslexic children in the interaction but also can help them develop their excess.

Based on the result of an interview with the manager of Griya Baca, Pelangi described the fact that dyslexic child is growing far from approximation, they have quick response and their communication with their same-age friends are very normal as the children in general. Besides, some dyslexic children can respond quickly to what the teacher gives. Dyslexic children are more inclined to be systematic and on time. Their imagination also develops far from the approximation. For an adult, this matter may be something incredible because, at a young age, they can develop their imagination. It is true of what has been explained before that dyslexic children have different characteristics even more with their excess. In the Griya Baca Pelangi, all dyslexic children have their characteristics and excess. Dyslexic children have different levels starting from 4 years to the age of 13 years. Certainly, all children have been assessed and confirmed that the children are categorized as dyslexia.

This research describes the interpersonal communication skill of a dyslexic child. This research aims to study how the communication of a dyslexic child, remembering that a dyslexic child is experiencing language barriers. In the guidance and counseling service, communication skills can be improved through group guidance service and can be combined with responsive service in the form of individual counseling and group counseling. 


\section{RESEARCH METHOD}

The research approach applied in this research is qualitative research that uses a case study method. This research was done in Griya Baca Pelangi Kartasura Sukoharjo. The subject was chosen using the purposive sampling technique; the subjects were dyslexia students. The subject was selected based on the existing characteristics, such as having a problem differentiating numbers and letters, reading and spelling, and having a problem remembering an alphabet and table; besides what has been mentioned, the most prominent of dyslexic child characteristics is low self-confidence. The research subjects of this research are three dyslexia students aged 6,7 , and 9 years whereas all of them have been taken to the doctor and psychologist. The data collection method was done in a natural setting and primary data resource, and the data collection technique was more on participant observation, in-depth interview, and documentation. The research instruments that used in this research were observation and interview guidelines. In addition, this research applied technique triangulation and sources triangulation to validate the data. The technique triangulation was an interview, observation, and documentation. The sources triangulation examined the data credibility obtained from some sources, for example, the students who became the research subject, the teacher, and the parents of the students. The data were analyzed by Miles and Huberman's data analysis technique in this research. The technique consisted of three steps: data reduction, data presentation, and conclusion drawing. Then, the conclusion was from data input to data presentation.

\section{RESULTS AND DISCUSSIONS}

The result of the research can be described as follows. Subject 1 initialed $V d$ is less in communication because $\mathrm{Vd}$ is not familiar with adapting to the environment. $\mathrm{Vd}$ tends to be alone and more focused on himself. Vd has some obstacles such as being individualist, lack of social languages, his spoken language (non-verbal) is enough, and lack of verbal. This matter makes $\mathrm{Vd}$ has trouble communicating with his interlocutors.
However, the obstacle does not detain Vd to continue his learning; although he has a special condition, $\mathrm{Vd}$ is learning continuously and ignores the people's perceptions about him. Vd's silence does not mean he cannot communicate completely; Vd will speak actively if the interlocutors are the people whom $\mathrm{Vd}$ has been known. For example, his family. When Vd is around his family, he will speak actively, give many questions, and be critical. However, when he is in the social environment, Vd cannot accept all of around him. Vd's response to the social world is lacking, so the people who do not understand will have misunderstood, whereas $\mathrm{Vd}$ is dyslexia.

Subject 2 initialed El is very active, critical, and enthusiastic about the social world. El is considered a child who is adaptable; he can start conversations with new people he meets. El can adapt himself; he can start and be involved in communication. El's personality that cheerful, critical, and adaptable are the matters loved by his friends. His teacher often trusts El to lead the prayer or the gymnastic. El has an obstacle, but it does not influence his young ages life.

Subject 3 initialed $R a$ is critical enough to ask his teacher and mother. Ra is considered as a child that smart enough in the adaptation. $\mathrm{Ra}$ often uses spoken language rather than symbol sign language to share his message or want. Ra has some obstacles in the communication, such as telling a long story and talking with the interlocutors face to face. $\mathrm{He}$ has a fear of talking because he usually passes the verb in talking, so Ra needs to be directed when communicating. $\mathrm{Ra}$ is smart enough in adaptation, but he still needs time to adapt when he meets new people. $\mathrm{Ra}$ is a critical student who has many questions for his teacher during the learning process. He is often joining and follows his friend's learning process when studying.

Interpersonal communication is an important part of the teacher instructional process and dyslexic children. It is not only interpersonal approach, the teacher is also charged to decide the right way for improving the children's reading ability. One method that can be used is the multi-sensory teaching 


\section{4 | PSIKOPEDAGOGIA}

approach (Juliansyah, 2019; Ruhaena, 2015). During the covid, the teacher and dyslexic children have more challenges. For example, online therapy done by the shadow teacher and dyslexic children during the covid-19 pandemic, applied a communication pattern generally called the unbalanced split and the monopoly pattern for dyslexic children with special conditions (Ardy:2020).

The analysis result showed that every child has communication difficulties. It is based on the nine aspects follows:

Source/communicator aspect: The three of the subjects are dyslexic children, but they have different difficulties and levels in communication. $\mathrm{Vd}$ is considered an introverted child with less adaptation ability, less social ability, tends to be individualist, and needs to be provoked to make him start a conversation. $\mathrm{Vd}$ also will be quiet around new people, and his concentration distracted when he is studying.

Message aspect. The three dyslexia students have differences in conveying their messages. $\mathrm{Vd}$ does not like funny things, $\mathrm{Vd}$ prefers to play when he should talk about funny things, and $\mathrm{Vd}$ prefers face-to-face communication. Likewise, with El, he prefers to play, El does not convey his message using symbols, and he prefers to convey his message directly and face to face. Then, Ra does not like to talk about funny things, but he likes it when he is watching cartoons or animations. Ra does not like to use symbol signs to communicate, and he prefers face-toface communication to help him understand the communication goals quickly.

Channel/media aspect. Media use in communication is needed, but not all communication needs media. Vd, El, and Ra do not use special media in communication; however, media may be needed for longdistance communication, so the three of them can use a handphone and voice note or a phone call (more effective). They used media communication only a few times, which can be counted. They are often conveying their message through phone calls.

Receiver/communicant aspect. Vd's friends respond to $\mathrm{Vd}$ very well, but $\mathrm{Vd}$ rarely gives feedback or asks his friends back. Vd's friends are quite a lot, but not all love him. Vd tends to be asked than starting the conversation, so he needs to be provoked for starting a conversation. El and Ra included as their friend's favorite children. El and Ra's friends like to ask them, and they will give their responses and give their friends a question. Besides, El and Ra can be started and start the communication. They will be active and give many questions if they have familiar with the people.

Decoding aspect. In the communication, $\mathrm{Vd}, \mathrm{El}$, and Ra always pay attention and listen to their interlocutors firstly; then, they give their response. For example, when their friend feels sad, they can not fully understand it, but $\mathrm{El}$ and Ra quite understand the interlocutor's facial expressions.

Response aspect. The three of $\mathrm{Vd}, \mathrm{El}$, and $\mathrm{Ra}$ have a different responses. Vd does not answer all of his friends who ask him; he only answers the closest and most familiar people. Vd's response to his friends is just normal. The rejection occurs if the statement and the question are not appropriate. El always responds to his friends, and he rarely does not respond to his interlocutor, even though there is a rejection because it is inappropriate. $\mathrm{El}$ is a child who is open to anyone. Then, Ra does not immediately answer the question from a new person when he talks with his friends, but if he has known the people for a long time, $\mathrm{Ra}$ will not be awkward. There is also a rejection because it was inappropriate for Ra's character.

Distraction aspect. Distractions for the three of them are in the form of fear of different difficulties they experienced. Vd will be afraid to communicate with new people and will find difficulties if the questions are difficult, and he asked to tell stories. El is not afraid to communicate with anyone and will find difficulties telling stories. Ra will be afraid if he meets new people and will find it difficult to give feedback so that he only conveys the main words while the verbs are almost past.

Communicant context aspect. The context of communication includes place, time, and behavior. In the context of communication, the 
three of the students have similarities. They communicate wherever they feel comfortable. There is no time limit; they are also happier if the other person speaks in a low voice and does not scream. The three will pay close attention when the other person is older. El will treat his friends the way his friends treat him. Besides, Vd and Ra do not fully understand manners, but they gradually understand them.

The study results can be concluded that each student has the ability and experiences an obstacle or problem with different symptoms in communication. They have different communication skills, which can be seen in adapting to the environment. For example, being afraid of people when he is communicating is one of the symptoms for dyslexic children. The three of the student experienced the same thing.

The first student also had difficulty communicating with the interlocutors. The second student (EI) is very active and adaptable to his environment; his only obstacle is his lack of writing letters. The third student is not much different from the second student; however, he has difficulty communicating his idea; he only can convey the main word such as "Ra eat," the verb in that word does not exist, so that sometimes there are several sentences that are not appropriate when he is communicating.

All three students have different characteristics and different abilities. Communication skills can be trained on anyone regardless of who the person is. Communication skills have begun to be trained from childhood until now without time limitation. The more you communicate, the more vocabulary you have so that when communicating with friends, you do not need to confuse in conveying. Interpersonal communication skills are needed in socialization, and it is to maintain relationships between one person and another. As stated by Asrowi and Barida (2013) in their research, interpersonal communication prioritizes relationships with human beings. A successful person is someone who can maintain good relationships with other people. Pictures or visuals can support interpersonal communication skills to make it familiar.
Dyslexic children are more creative and innovative in visuals, so what dyslexic children convey is by what they see.

Communication skills can be trained in assertive communication skills training; it is the training that trains students to express their feelings and thoughts clearly without offending others (Asrowi and Barida, 2013). It can be applied to dyslexic children because the more they are trained in communication, the better it is. The more dyslexic children talk, the more vocabulary and sentences they will have. Communication skills in dyslexic children do not suddenly understand and respond quickly, but in the process, discussing with dyslexic children is difficult. It is strengthened by Hariko (2017), who stated that communication could not be separated from the activity experienced by an individual. Its existence is far beyond space and time for different purposes and touches all aspects of human life. Communication skills in dyslexic children can be maintained and developed by educators at schools and parents, so what is conveyed by dyslexic children can be understood by many people.

Dyslexic children have different abilities to process information. According to Gallardo et al. (2013), dyslexia has differences in information processing abilities, mainly affecting the ability to read, write, and spell. However, it also can impact cognitive processes such as memory, information processing speed, time management, coordination, and automaticity. Wang and Yang (2011), Achdiyat \& Utomo (2018) investigated the visual-spatial ability of dyslexia students in China and Taiwan aged 10-12 years. The results showed no significant differences between dyslexia and normal children. However, they found significant differences in the response speed of dyslexic children when compared to the control of their minds. It indicates that individuals with dyslexia have improved their visual-spatial abilities based on faster response times without increasing the error rates. Dyslexic children are not weak in all aspects; the research by Wang Yan shows that dyslexic children surpass in their visuals. 


\title{
6| PSIKOPEDAGOGIA
}

\author{
JURNAL BIMBINGAN DAN KONSELING
}

Vol.10, No.1, June 2021

Dyslexic children are intelligent children; it is proved by their ability to recognize images faster than writing. Dyslexic children are classified as intelligent children, and their abilities can be said as superior. It is strengthened by Bilgehan (2017); Lidwina (2012), who argued that dyslexia is defined as special learning difficulties with individual intelligence that is normal or superior. Some parents or peers think that dyslexic children are different from normal children aged 5-7 years who can read and write. Many experts admit that between $5-10 \%$ of children with dyslexia have difficulty reading and writing. It is reinforced by Emine and Aybala's (2018) research results which showed that most dyslexia students have spelling problems $(35 \%)$ and fluent reading problems $(51 \%)$. The proportion of students who can only learn letters $(5 \%)$ and students who have never learned to read $(7 \%)$ is very small.

Adaptation in terms of communicating for dyslexic children can be said as unique. Rahmat (2008) revealed that there is no individual can live a normal life without the process of communicating or talking to other people. Normal people may easily convey what they want, but not with the people who have special needs, especially dyslexic children. Dyslexic children want to convey what they want, but what can they do if the method they use still makes people confused about what they want. In other words, dyslexic children have communication difficulties.

Certainly, the era's development makes communication easier, both directly and through social media. Winda et al. (2014); Watie (2016) stated that the advantage of communication through social media is that it can be done easily, even at long distances. However, communication through social media is the lack of openness and empathy towards the interlocutor.

Children with special needs, especially dyslexia, communicate using pictures or visuals. For them, using images or visuals is the easiest way to communicate. Parents or teachers who do not understand how they communicate will find it a little difficult. The way to communicate with dyslexic children may be different, but parents or teachers can develop ways of communication using images or visuals as intermediaries. It is an advantage for dyslexic children. Mathematical communication skills increase if parents and teachers pay more attention to how the children learn and their shortcomings, such as their lack of reading and writing skills.

Dyslexic children tend to be punctual and follow a pattern, but the patterns between dyslexic children differ. Some feel bored easily, and some feel very concerned about their environment. The teaching process used visuals and practices. The learning style applied in the learning also tends to be visual and kinesthetic. The activities are associated with visuals and are motor movements, so the children do not get bored easily.

The social interaction of dyslexic children in Griya Baca Pelangi is also quite good. These dyslexic children are not completely constrained in terms of socialization; they are quite active and adaptive to the environment. The learning process is carried out one by one, but it has different targets for each child.

The evaluation done in Griya Baca Pelangi used a different method for dyslexic children; the questions used are not the same as questions for normal children. This school views that dyslexic children have very high imaginations and extraordinary abilities so that if they are given general questions, they will give different answers. Therefore, the questions made for dyslexic children are adjusted to their abilities. The obstacle in dealing with dyslexic children is that they are more on time, so their perceptions must be aligned with others. Children with dyslexia should also be given the same understanding but told in a way that is easy to understand.

Table 1

Data Presentation

\begin{tabular}{|c|c|c|c|}
\hline & Subject 1 & Subject 2 & Subject 3 \\
\hline $\begin{array}{l}\text { Sourc } \\
\text { e/com } \\
\text { munic } \\
\text { ator }\end{array}$ & $\begin{array}{l}\text { Vd is } \\
\text { introvert, he } \\
\text { prefers to be } \\
\text { alone, and } \\
\text { does not pay } \\
\text { too much } \\
\text { attention to } \\
\text { other } \\
\text { people's }\end{array}$ & $\begin{array}{l}\text { El is an } \\
\text { adaptable } \\
\text { child, he is } \\
\text { happy when } \\
\text { people talk } \\
\text { to him. El } \\
\text { also feels } \\
\text { happy for } \\
\text { the people }\end{array}$ & $\begin{array}{l}\text { Ra is an } \\
\text { adaptable } \\
\text { child; he is } \\
\text { happy when } \\
\text { he is around } \\
\text { the people. } \\
\text { He is happy } \\
\text { when people }\end{array}$ \\
\hline
\end{tabular}




\begin{tabular}{|c|c|c|c|}
\hline & $\begin{array}{l}\text { concerns for } \\
\text { him. }\end{array}$ & $\begin{array}{l}\text { who care to } \\
\text { him. }\end{array}$ & $\begin{array}{l}\text { talk and care } \\
\text { to him. }\end{array}$ \\
\hline $\begin{array}{l}\text { Encodi } \\
\text { ng }\end{array}$ & $\begin{array}{l}\text { Vd prefers } \\
\text { to convey } \\
\text { his wishes } \\
\text { directly } \\
\text { rather than } \\
\text { writing them } \\
\text { down, but } \\
\text { Vd also likes } \\
\text { conveying } \\
\text { messages } \\
\text { using } \\
\text { symbols. Vd } \\
\text { likes it when } \\
\text { his } \\
\text { interlocutor } \\
\text { responds } \\
\text { him and he } \\
\text { does not } \\
\text { care when } \\
\text { no one } \\
\text { responds. }\end{array}$ & $\begin{array}{l}\text { El prefers to } \\
\text { speak in } \\
\text { conveying } \\
\text { his wishes } \\
\text { rather than } \\
\text { using } \\
\text { symbol } \\
\text { signs. El is } \\
\text { happy when } \\
\text { his friend } \\
\text { responds } \\
\text { him, but El } \\
\text { will also be } \\
\text { normal if no } \\
\text { one } \\
\text { responds to } \\
\text { him. }\end{array}$ & $\begin{array}{l}\text { Ra prefers to } \\
\text { speak rather } \\
\text { than writing. } \\
\text { Ra does not } \\
\text { use symbol } \\
\text { signs when } \\
\text { communicatin } \\
\text { g with his } \\
\text { interlocutor. } \\
\text { Ra is also very } \\
\text { happy when } \\
\text { his friend } \\
\text { responds him. } \\
\text { Ra is not too } \\
\text { sad when no } \\
\text { one responds; } \\
\text { instead, Ra } \\
\text { invites the } \\
\text { others to } \\
\text { communicate. }\end{array}$ \\
\hline $\begin{array}{l}\text { Messa } \\
\text { ge }\end{array}$ & $\begin{array}{l}\text { Vd prefers } \\
\text { to play. In } \\
\text { delivering } \\
\text { messages, } \\
\text { Vd often } \\
\text { conveys his } \\
\text { message by } \\
\text { speaking, } \\
\text { but } \\
\text { sometimes } \\
\text { he also uses } \\
\text { symbol } \\
\text { signs. Vd } \\
\text { also prefers } \\
\text { to deliver } \\
\text { messages } \\
\text { face-to-face } \\
\text { rather than } \\
\text { over the } \\
\text { phone. }\end{array}$ & $\begin{array}{l}\text { El is the type } \\
\text { of child who } \\
\text { likes to play } \\
\text { rather than } \\
\text { talk about } \\
\text { funny things. } \\
\text { El does not } \\
\text { use symbols } \\
\text { when } \\
\text { communicati } \\
\text { ng, he is } \\
\text { direct and } \\
\text { face-to-face. }\end{array}$ & $\begin{array}{l}\text { Ra does not } \\
\text { like funny talk, } \\
\text { and he does } \\
\text { not like } \\
\text { symbolic } \\
\text { messages. Ra } \\
\text { prefers to be } \\
\text { face to face } \\
\text { when } \\
\text { communicatin } \\
\text { g. }\end{array}$ \\
\hline $\begin{array}{l}\text { Chann } \\
\text { els/ } \\
\text { Media }\end{array}$ & $\begin{array}{l}\text { Vd is rare } \\
\text { using media } \\
\text { in } \\
\text { communicati } \\
\text { ng; he only } \\
\text { uses HP } \\
\text { when he } \\
\text { need to } \\
\text { communicat } \\
\text { e remotely. }\end{array}$ & $\begin{array}{l}\text { El does not } \\
\text { use special } \\
\text { media in } \\
\text { communicati } \\
\text { ng. El only } \\
\text { uses HP to } \\
\text { communicat } \\
\text { e remotely. } \\
\text { In addition, } \\
\text { El rarely } \\
\text { uses } \\
\text { symbols } \\
\text { when } \\
\text { communicati } \\
\text { ng }\end{array}$ & $\begin{array}{l}\text { Ra does not } \\
\text { use media in } \\
\text { communicatin } \\
\mathrm{g} \text {, he only } \\
\text { uses HP for } \\
\text { several times. } \\
\text { It is because } \\
\text { Ra prefers } \\
\text { face to face to } \\
\text { communicatio } \\
\mathrm{n} \text {. }\end{array}$ \\
\hline $\begin{array}{l}\text { Receiv } \\
\text { er/Co } \\
\text { mmuni } \\
\text { cant }\end{array}$ & $\begin{array}{l}\text { Vd is very } \\
\text { rare to ask } \\
\text { his friends } \\
\text { bact after } \\
\text { they talk to } \\
\text { him, and not } \\
\text { all his } \\
\text { friends are } \\
\text { happy to ask } \\
\text { Vd. Vd can } \\
\text { start a } \\
\text { conversation } \\
\text { with his } \\
\text { closest. }\end{array}$ & $\begin{array}{l}\text { El feels } \\
\text { happy when } \\
\text { his } \\
\text { interlocutor } \\
\text { responds to } \\
\text { him, and El } \\
\text { will ask } \\
\text { again. Then, } \\
\text { El can start } \\
\text { a } \\
\text { communicati } \\
\text { on. It makes } \\
\text { El's friends } \\
\text { love him. }\end{array}$ & $\begin{array}{l}\text { Ra's friends } \\
\text { are happy to } \\
\text { ask Ra. Ra } \\
\text { responds his } \\
\text { friends and } \\
\text { asks them } \\
\text { again. Ra can } \\
\text { invited and } \\
\text { can be invited } \\
\text { in a } \\
\text { conversation. } \\
\text { Sometimes } \\
\text { Ra's friends } \\
\text { start the } \\
\text { conversation, }\end{array}$ \\
\hline
\end{tabular}

\begin{tabular}{|c|c|c|c|}
\hline & & & $\begin{array}{l}\text { but Ra often } \\
\text { starts the } \\
\text { conversation } \\
\text { first. }\end{array}$ \\
\hline $\begin{array}{l}\text { Decodi } \\
\text { ng }\end{array}$ & $\begin{array}{l}\text { Vd pays } \\
\text { attention and } \\
\text { listens well } \\
\text { to the } \\
\text { interlocutor. } \\
\text { Vd does not } \\
\text { understand } \\
\text { the feeling of } \\
\text { sad; he only } \\
\text { feels } \\
\text { confused } \\
\text { about what } \\
\text { happened. }\end{array}$ & $\begin{array}{l}\text { El will pay } \\
\text { attention and } \\
\text { listen well to } \\
\text { the } \\
\text { interlocutor. } \\
\text { However, El } \\
\text { does not } \\
\text { have a } \\
\text { sense of } \\
\text { empathy yet } \\
\text { for his } \\
\text { friends. }\end{array}$ & $\begin{array}{l}\text { Ra will pay } \\
\text { close } \\
\text { attention, } \\
\text { starting from } \\
\text { facial } \\
\text { expressions. } \\
\text { Ra listened } \\
\text { well when his } \\
\text { friend spoke. } \\
\text { Ra will also } \\
\text { feel sad when } \\
\text { his friend is } \\
\text { sad. }\end{array}$ \\
\hline $\begin{array}{l}\text { Respo } \\
\text { nse }\end{array}$ & $\begin{array}{l}\text { Not all who } \\
\text { asked Vd to } \\
\text { communicat } \\
\text { e answered. } \\
\text { Vd only } \\
\text { answered } \\
\text { people he } \\
\text { knew and } \\
\text { several } \\
\text { times } \\
\text { refused } \\
\text { because he } \\
\text { is not } \\
\text { comfortable } \\
\text { with the } \\
\text { communicati } \\
\text { on topic. }\end{array}$ & $\begin{array}{l}\text { El is a } \\
\text { humble child } \\
\text { and he feels } \\
\text { happy when } \\
\text { someone } \\
\text { asks him. } \\
\text { Therefore, El } \\
\text { rarely } \\
\text { refuses a } \\
\text { conversation } \\
\text { unless it } \\
\text { does not suit } \\
\text { him. }\end{array}$ & $\begin{array}{l}\text { Ra will } \\
\text { immediately } \\
\text { respond when } \\
\text { the interlocutor } \\
\text { is known, but if } \\
\text { he is new, Ra } \\
\text { will answer } \\
\text { briefly. Ra } \\
\text { does not } \\
\text { respond if it } \\
\text { does not suit } \\
\text { him. }\end{array}$ \\
\hline $\begin{array}{l}\text { Distur } \\
\text { bance }\end{array}$ & $\begin{array}{l}\text { Vd is afraid } \\
\text { of new } \\
\text { people and } \\
\text { finds it } \\
\text { difficult when } \\
\text { he cannot } \\
\text { answer a } \\
\text { question. He } \\
\text { also has a } \\
\text { problem } \\
\text { when } \\
\text { someone } \\
\text { asked him to } \\
\text { tell stories. }\end{array}$ & $\begin{array}{l}\text { El does not } \\
\text { feel afraid of } \\
\text { anyone } \\
\text { when } \\
\text { communicati } \\
\text { ng because } \\
\text { El likes } \\
\text { being social. } \\
\text { However, El } \\
\text { finds it } \\
\text { difficult when } \\
\text { the } \\
\text { questions } \\
\text { are difficult } \\
\text { and he } \\
\text { should tell } \\
\text { stories. }\end{array}$ & $\begin{array}{l}\text { Ra } \\
\text { experiences } \\
\text { fear when } \\
\text { dealing with } \\
\text { people, and } \\
\text { Ra finds it } \\
\text { difficult when } \\
\text { he is in he } \\
\text { should talk } \\
\text { with new } \\
\text { people. }\end{array}$ \\
\hline $\begin{array}{l}\text { Comm } \\
\text { unicati } \\
\text { on } \\
\text { contex } \\
t\end{array}$ & $\begin{array}{l}\text { Vd } \\
\text { communicat } \\
\text { es anywhere } \\
\text { without a } \\
\text { time limit } \\
\text { and he feels } \\
\text { happy if the } \\
\text { other person } \\
\text { conveys it } \\
\text { slowly. }\end{array}$ & $\begin{array}{l}\text { El } \\
\text { communicat } \\
\text { es anywhere } \\
\text { without a } \\
\text { time limit } \\
\text { and he feels } \\
\text { happy when } \\
\text { his friend } \\
\text { speaks in a } \\
\text { soft voice. }\end{array}$ & $\begin{array}{l}\text { Ra } \\
\text { communicates } \\
\text { anywhere and } \\
\text { is not limited } \\
\text { by time. Ra } \\
\text { also feels } \\
\text { happy when } \\
\text { his interlocutor } \\
\text { speaks in soft } \\
\text { and slowly. }\end{array}$ \\
\hline
\end{tabular}

\section{CONCLUSION}

Based on the conclusions of each subject, the cases of each dyslexic child are different. Interpersonal communication skills become a skill for each individual to facilitate socialization. However, in training communication skills, a teacher is also 


\section{8 | PSIKOPEDAGOGIA}

JURNAL BIMBINGAN DAN KONSELING

Vol.10, No.1, June 2021

needed to guide the students to develop their abilities. Besides the parents, teachers also have an important role in the student's social relations development. These communication difficulties need to be considered by the BK teacher. Services in Guidance and Counseling have prevention functions, development functions, and curative functions. One of the services in BK is basic services that consist of classical guidance, group guidance, large class guidance, and media development.

Communication skills can be improved through group guidance services, and they can also be combined with responsive services in the form of individual counseling or group counseling.

\section{REFERENCE}

Achdiyat, M., \& Utomo, R. (2018). Kecerdasan Visual-Spasial, Kemampuan Numerik, Dan Prestasi Belajar Matematika. Formatif: Jurnal IImiah Pendidikan MIPA, 7(3).

Amin, B. (2018). Parental Acceptance terhadap Anak dengan Disleksia dalam Film Wonderful Life. INKLUSI Journal of Disability Studies, 5(1), 133-152.

Ardy Z, M. A. (2020). Pola Komunikasi Guru Pendamping Dengan Anak Disleksia Selama Pandemi Covid-19 (Studi Deskriptif Kualitatif Pola Komunikasi Guru Pendamping Dengan Anak Disleksia Dalam Meningkatkan Kemampuan Berbahasa Pada Sekolah Layanan Terapi Disleksia Sebaya Sidoarjo) (Doctoral dissertation, UPN" VETERAN" JATIM).

Asrowi dan Barida, M. (2013). The Effectiveness of Asserive Training to Increase the Communication Skills of High School Students in Surakarta. DIJE, 1(1).

Bilgehan, E. (2017). Music and Dyslexia: The Therapeutic Use of Instrument (Piano) Training with a Child with Dyslexia (A Case Study). Journal of Education and Practice, 8(23).

Bishop-Liebler, P., Welch, G., Huss, M., Thomson, J. M., \& Goswami, U. (2014). Auditory Temporal Processing Skills in Musicians with Dyslexia. Dyslexia, 20(3), 261-279.
Devina, G., \& Penny, H. (2016). Gambaran Proses Penerimaan Diri lbu yang Memiliki Anak Disleksia. IJDS: Indonesian Journal Of Disability Studies, 3(1), 44-52.

Emine, B \& Aybala, C. (2018). Reading Performance Profile of Children with Dyslexia in Primary and Secondary School Students. Journal of Education and Learning, 7(1).

Flaugnacco, E., Lopez, L., Terribili, C., Montico, M., Zoia, S., \& Schön, D. (2015). Music Training Increases Phonological Awareness and Reading Skills in Developmental Dyslexia: A Randomized Control Trial. PloS one, 10(9), e0138715.

Gallardo, M. (2013). Supporting Students With Dyslexia in Distance Modern Language Studies. A Guide To Good Practice.

Hariko, R. (2017). Landasan Filosofis Keterampilan Komunikasi Konseling. Jurnal Kajian Bimbingan dan Konseling, 2(2), 41-49

ljeoma, A. (2018). Brainfeed Intervention Programme: an Alternative Approach for Supporting People Living with Dyslexia. Journal Of Education \& Enterpreneurship, 5(2), 124-143.

Juliansyah, A. (2019). Komunikasi Instruksional pada Anak Disleksia di Sekolah Dasar. Jurnal Dimensi Pendidikan dan Pembelajaran, 6(3), 119-131.

Lidwina, S. (2012). Disleksia Berpengaruh Pada Kemampuan Membaca dan Menulis. Jurnal STIE Semarang (Edisi Elektronik), 4(3), 09-18.

Ningsih, D. A. P., Legowo, E., \& Hidayat, R. R. (2017). Peningkatan Keterampilan Komunikasi Lisan Siswa sebagai Fungsi dari Teknik Instruksi Diri. Jurnal Kajian Bimbingan dan Konseling, 2(3), 86-96.

Rahmat, J. (2008). Psikologi Komunikasi. Bandung: Remaja Rosda Karya.

Ruhaena, L. (2015). Model Multisensori: Solusi Stimulasi Literasi Anak Prasekolah. Jurnal Psikologi, 42(1), 47-60.

Wadlington, E., \& Wadlington, P. (2005). What Educators Really Believe About Dyslexia, Reading Improvement, 42, 16-32.

Wang, L., \& Yang, H. (2011). The Comparison of The Visuo-Spatial 
Abilities of Dyslexic and Normal Students In Taiwan and Hong Kong. Research in Developmental Disabilities, 32(3), 1052-1057.

Watie, E. D. S. (2016). Komunikasi dan Media Sosial (Communications and Social Media). Jurnal The Messenger, 3(2), 69-74.

Winda, M., dkk. (2014). Komunikasi Interpersonal Siswa Pengguna Internet dan Implikasinya terhadap Layanan Bimbingan dan Konseling. Jurnal Konseling dan Pendidikan, 2(1), 8-14 